\title{
Sustainability of Climate Change Adaptation Strategies: Experiences from Eastern Ghana
}

\author{
Frank Kwaku Agyei (Corresponding author) \\ University College of Agriculture and Environmental Studies \\ Post Office Box 27 Bunso Eastern Region, Ghana \\ Tel: 0023-3243-739-288Ｅ-mail: frankkagyei@yahoo.com
}

Received: May 17, 2016 Accepted: June 11, 2016

doi:10.5296/emsd.v5i2.9845 URL: http://dx.doi.org/10.5296/emsd.v5i2.9845

\begin{abstract}
Climate change risks are wide spread, and they are transforming the socio-environmental infrastructure of economic development. Whether they are included or not in the development of national adaptation strategies, rural populations continue to employ diverse climate adaptation strategies to withstand climate induced vulnerabilities inimical to their livelihoods. Using the case of farming communities in Eastern Ghana and through semi-structured interviews, this article addresses the questions: which climate risks confront farmers, what are farmers' adaptation choices, and which adaptation strategies are sustainable and why? The paper argues that farmers use range of adaptation strategies to minimize climate risks. Nevertheless, some strategies do not sustain the anticipated positive outcomes. Local choices of adaptation strategies were skewed towards advancing general income, and poorly promoted healthy ecological systems. Farmers' choices of climate strategies were based on, among others, personal intuition or historical experience, knowledge of strategies, and availability of resources to implement a particular strategy: sustainability measures weakly influenced selections. Short rotation and mixed species cropping, farming at several locations, and drought tolerant crop varieties were sustainable initiatives to farmers. The main qualities of successful initiatives were low cost strategy, economic equity, and flexibility to precipitation and temperature. Climate adaptation strategy can be sustainable if it is less costly to establish, and flexible to places and seasons.
\end{abstract}

Keywords: Climate Change, Climate Risk, Sustainability, Adaptation Strategy, Ghana

\section{Introduction: Climate Risks and Adaptation Strategies}

Predominantly, threats and hazards resulting from climate variability and change are wide spread and continue to transform the socio-environmental infrastructure of economic 
development. These risks affecting various aspects of society including livelihoods, health, food security, and biodiversity (Costello, 2009; Huber and Jay, 2011; UNFCCC, 2008), are more deterrent to rural populations overwhelmingly dependent on the natural resources in generating their livelihoods (FAO, 2005; IPCC, 2001; Kreft et al., 2015; UNFCCC, 2008). Typically, farmers in the developing world encounter numerous traditional risks such as political instability, insecure land tenure, input and market access, and price-related risks (Binswanger-Mkhize, 2009; Livingstone et al., 2011; Salami et al., 2010). However, when traditional risks are superimposed with extreme climatic conditions, impacts of diverse nature and time scale could be sustained (Scheffran, and Battaglini, 2011; Scheffran et al., 2012). Climate induced threats are not getting any better, risk indicators for critical problems categorized over two-thirds of the world to be highly vulnerable (Wheeler, 2011), and the future climate risk scenario is anticipated to be severe with subsequent rising odds in health, livelihoods, and economic conditions (Cayan et al., 2010; Cayan et al., 2013; Meehl et al., 2007). Climate change is therefore labeled as a top global menace with its impacts cutting across socio-economic and political spheres (IPCC, 2007; OECD, 2008).

Over the last few years, however, adequate attention has been given to climate change. The urgency of climate safety concerns and implications for human and biophysical systems have led to the recognition of adaptation response as one of the candid policy option for reducing the negative impact of climate change (IPCC, 2007). Adaptation strategies include series of activities to reduce the vulnerability of natural and human systems against expected climate change effects. Typical examples under farming system include the use of drought resistant crops, changing planting times, and keeping personal savings or insurance to cover the expected damage (IPCC, 2001; Toman and Bierbaum, 1996). Thus, adaptation protocols focus on the consequences of climate change by making behavioral, institutional and technological adjustments. By now, almost all countries have integrated a national climate change adaptation response strategy into government policies, and others are in the process of integrating initiatives into local government development policies and plans (UNDP, 2010; USAID, 2012). Parallel to international and state efforts in the development of climate adaptation policy frameworks, local communities employ various adaptation responses to withstand climate induced vulnerabilities against their livelihoods (Ajani et al., 2013; Memmott et al., 2013). This has resulted in intense spread of forms of adaptation strategies across cultures, states, and regions (Murdiyarso and Kauffman, 2011; Murdiyarso et al., 2012; Sivakumar and Stefanski, 2008). However, little is known about the extent climate adaptation strategies are sustainable.

Sustainable climate strategies are crucial for productive livelihoods and healthy environment, but few empirical studies have in detail investigated the sustainability of climate adaptation strategies (Actionaid, 2012; UNDESA, 2008). This paper uses the case of farming communities in Eastern Ghana to address the questions: which climate risks confront farmers, what are farmers' adaptation choices, and which adaptation strategies are sustainable and why? The paper argues that, farmers in Eastern Ghana employ various climate adaptation strategies to withstand risks confronting their livelihoods, but few strategies such as short rotation and mixed species cropping were sustainable. Farmers' choices of adaptation strategies were 
skewed towards advancing general income, thus promoting economic sustainability. These choices poorly promoted environmental benefits. Two, farmers' choices of climate strategies were based on, among others, historical experiences, knowledge of strategies, and availability of resources to implement a particular strategy. Three, the main qualities of sustainable adaptation strategies were low cost strategy, economic equity, and flexibility to precipitation and temperature.

In section two, the paper outlines the main features of the sustainability theory as an analytical framework. Section three provides a brief contextual background of climate change discourses in Ghana. This is followed by the approach for data collection and analysis. Then, the presentation of the results and discussions follows in that order.

\section{The Concept of Sustainability}

Among the many ways that sustainability has been defined, the simplest and most fundamental is: "the ability to sustain" or, put another way, "the capacity to endure." SustainAbility

Sustainability is one of the most fraught and contested concepts in the social sciences. It was after the 1972 report dubbed 'Limits of Growth' that the concept of sustainability attained great public attention. In 1980, the International Union for the Conservation of Nature together with the U.N. Environment Programme, and World Wildlife Foundation developed the world conservation strategy to generate international attention for sustainability. Over the years, the concept has emerged to incorporate two models of sustainability; "strong" and "weak" approaches (Jenkins, 2010). "Strong sustainability" maintains strict preservation of ecological goods such as the protection of forest estate to maintain its status quo without any modification. "Weak sustainability" on the other hand, avoid specific duties to sustain any particular good, but aims at not leaving future generations in a worse situation (Jenkins, 2010). For instance, a strong sustainability approach will aim at conserving a forest estate just as it is for years by even avoiding development in the forest area, but a weak sustainability would assess the future value of the forest, use the forest estate, and provide alternative future conditions for the future generation.

Complexities surrounding the organisation of sustainability around themes like 'weak' and 'strong' have seen a gradual shift towards its conception as models of sustainability: economic, environment, and social. An economic model seeks to sustain financial capital (World Bank, 2006). Promoting economic sustainability means current usage does not degrade or diminish the usefulness of resources for future generation while consistently returning a profit. Thus, the use of non-renewable resources should not prevent future generation from getting easy access to the resource, and should not reduce the real incomes of future generations (Markandya and Pearce, 1988). Hamrin (1983) explains that since the natural environment will serve as the foundation for economic transaction of future generation, their economic progress will also be based on the sustained integrity of the resource and environmental base. As such, economic sustainability advances indefinitely a defined level of economic production, and the underlying thrust is for the economic system to be profitable over time. 
Environmental sustainability advances the biological diversity and ecological integrity of a natural system. This focuses on the health quality of the natural environment, thus making it differ from the economic model whose unit of focus is creating capital (Rolston, 1994). Historically, the concept of sustainability was thought to be social and economic development that promotes environmental sustainability. However, the concept has evolved over the years from being perceived as 'environmentally responsible development', 'environmentally sustainable development' to 'environmental sustainability' (Serageldin and Streeter, 1993; Goodland, 1995). Goodland explains that the essence of environmental sustainability is to advance human welfare and at same time ensure that the sources of raw materials are not degraded to prevent harm to humans. Thus, environmental sustainability is the capacity to uphold the qualities valued in the physical environment (Sutton, 2004).

There is no single way that social dimension of sustainability is approached in theory and practice (Martin, 2001). This is because countries and societies vary with their socio-cultural conditions. Black (2004) explains social sustainability to be the extent social values and identities can be maintained into the future. Thus, the focus is to preserve social systems that realize human dignity. Gilbert et al. (1996) explain that social sustainability is achieved when the cohesion of society and its capacity to achieve common goals are upheld into the future. In brief, community is said to be sustainable when current processes and structures do not prevent future generation from enjoying healthy community.

\section{National Climate Adaptation Framework and Local Adaptation Practices in Ghana}

In Ghana, several measures have been implemented to control the impacts of climate change, key among them is the development of the national climate change adaptation strategy. The preparation of the national adaptation strategy took the path of inclusive development where key actors across the nation, sectors and districts participated. Forest fringe communities, farmers, and other users of the forest resources including chainsaw operators, saw millers, charcoal producers, and carpenters were not left out of the consultation process. It is anticipated that the strategy covers a period of 10 years from 2010 to 2020, and all actors comply by its directives. Besides the general goal and objectives to promote national resilient to climate risks, specific guidelines were formulated to guide the promotion of sustainability in the agricultural sector. The framework for the promotion of agricultural sustainability operationalise steps to strengthen local farmers' capacity, enhance their living conditions, ensure proper documentation of indigenous adaptation strategies, generate adequate trainers to advance post-harvest technologies, and strengthen extension officers' understanding and capacity in modern farming technologies (UNDP, 2012).

Parallel interventions include training of District Assemblies on mainstreaming climate change adaptation and disaster risk reduction, integration of climate change into the District Assemblies' functional organisation assessment tool which is a prerequisite for government budget allocation to the Assemblies for development projects. The District Assembly is the state body at the district level in charge of local administration. Similar programmes taking the form of collaborative development between international organizations, state institutions, and local communities include the Ghana Community Based Rural Development, 
Non-Legally Binding Instruments on all types of Forest in Ghana, Sustainable Land and Water Management Project, Livelihood empowerment project, Natural Resource Management Project, and GLOWA Volta Project (Osei-Owusu et al., 2012; Stanturf et al., 2011).

There are evidences indicating that local communities in Ghana employ various climate adaptation measures to endure climate risks (Gyampoh et al., 2011; Osei-Owusu et al., 2012). Osei-Owusu et al. (2012) document practices which could be categorized as indigenous and introduced strategies. In their study, adaptation practices such as mulching, loosening the soil, creating of bunds, and regular weeding were indigenous practices in the study areas, while the use of early maturing varieties, drought tolerant varieties, compost, and reduction of farm size were examples of introduced strategies (Osei-Owusu et al., 2012). Some local communities rely on the behavior and distribution of trees, frogs, birds, insects and clouds to predict rainfall patterns in their surroundings. This knowledge set has been evolved over the years as the locals observe the natural environment and deal with natural hazards. Particularly, communities in hazard prone areas have range of adaptive indigenous strategies which is obtained through their continual study and engagement with the environment (Gyampoh et al., 2011; Osei-Owusu et al., 2012). Therefore, the perspective and behaviour of indigenous people with respect to climate change and variability, and also their values are significant considerations in efforts to control climate change (Doss and Morris, 2001).

\section{Research Setting and Methods}

The study was conducted in three communities, Tafo, Bunso, and Asiakwa in East Akim Municipal District in the Eastern Region of Ghana (Figure 1). Eastern Region covers an area of 19,323 square kilometers, occupying 8.1 per cent of the total land area of Ghana, and is the sixth largest region of the country. It lies between latitudes $6^{\circ}$ and $7^{\circ}$ North and between longitudes $1^{\circ} 30^{\prime}$ 'West and $0^{\circ} 30^{\prime}$ East. The main occupations of the economically active population in the region are Agriculture and related work (54.8\%), Sales (14.3\%), Production, Transport and Equipment work (14.0\%) and Professional and Technical work (6.9\%) with Services accounting for 5.0 per cent (GOG, 2015). East Akim Municipal District was chosen to complement previous studies on climate change in the Ashanti and Brong Ahafo Regions (Gyampoh et al., 2009). The people of East Akim Municipal District are predominantly of the Akim tribe, but the area has seen the migration of the Ashanti's and the Brong-Ahafo people to engage in cocoa farming, the dominant cash crop in the area. The area also serves as home to certain Northern region tribes including the Frafra and the Dagomba. The study communities were purposively selected to reflect areas dominated by farming since the study sought to collect data from active farmers who might have experiences with climate risks and adaptation strategies. Farmers within the study communities cultivate various crops including plantain, cassava, maize, and vegetables, and others engage in animal farm such as cattle, sheep, and goats. Whilst a significant of farm produce is sent to commercial markets, most farmers conduct their farm works on subsistence basis to support the family feeding stock. 


\section{MInstitute Macrothink}

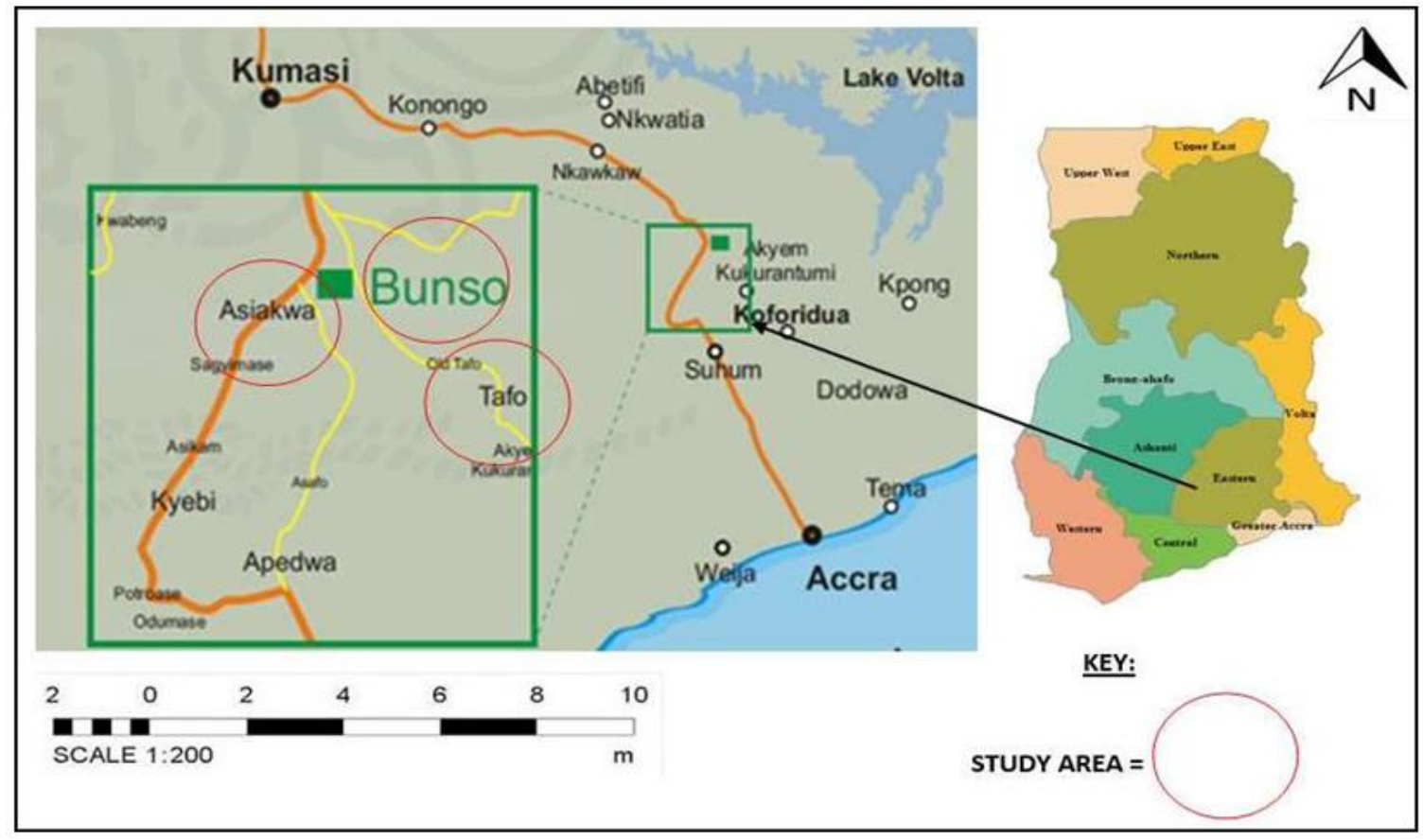

Figure 1. Map of Ghana showing the locations of Bunso, Asiakwa and Tafo in Eastern Ghana

The study targeted farm families for data collection; 15 farm families provided data in each community. Preliminary study revealed that farmers lived as families and were headed by males, but families whose husbands were dead or have travelled had female head. Typical families comprise of more than one household, usually a father and wife with matured sons and daughters. Matured sons with their wives might share same domestic functions with their parents like cooking together, but most were independent. Commonly, families cultivated on the same piece of land, thus shared similar farm experiences. The reconnaissance study also revealed that matured family heads requested family members, mostly their adult children to help them remember some facts. Against this, the study deemed it proper to use the family as the unit for data collection, and the analyses were also done at that level. The respondents were selected through systematic random sampling since it was practically impossible to know the exact population of farmers in the study communities. However, since the dominant livelihood in the area was farming, almost every house in the study communities had one or more farmers.

Data were collected with semi-structured questionnaires in February and March 2015 prior to the main farming season occurring from April to July. Prior to that, the questionnaires were tested and refined in January 2015 after interviewing five farm families at Bunso community. In each of the communities, the author consulted the assembly member (community representative under the local government structure), and members of the customary structure such as the chief and the elders for permission prior to engaging the farm families. All farm families approached were asked to participate in the study and those who expressed interest were interviewed. The semi-structured questionnaires collected data on demography and farm characteristics, climate risks affecting farmers, farmers' adaptation strategies, strategies sustaining farmers' incomes, environmental quality and social capital, and reasons for farmers' 
choices of strategies. The data were collected by the author using the Twi language, the local dialect of the respondents. The author speaks and writes fluently the Twi language. Duration of interviews ranged between 30 and 60 minutes. Data were entered and analysed in the Statistical Package for the Social Sciences (SPSS), Atlasti qualitative data analysis tool, and MS Excel. Statistics were mainly descriptive including means and frequencies.

\section{Results}

Section 5 presents data on climate risks confronting farmers in Eastern Ghana, farmers' choices of adaptation responses, and the extent farmers' choices of climate strategies are sustainable and why. Prior to that, the section provides the demography of participated farmers and their farm characteristics.

\subsection{Demography and Farm Characteristics}

All participated farmers were natives of their respective communities and had attained elementary education (Table 1). Mixed cropping, family labour, and family land were the dominant farming system, farm labour, and land tenure, respectively, for all farmers across the communities. All family heads at Asiakwa were males, but Tafo and Bunso had female family heads. Bunso recorded the highest age of the decision maker (51 years). Tafo recorded both the highest years spent by family head in farming (23 years), and the largest family size (6.4).

Table 1. Family and Farm Characteristics

\begin{tabular}{|c|c|c|c|}
\hline \multirow[t]{2}{*}{ Variables } & \multicolumn{3}{|c|}{ Communities } \\
\hline & Tafo $(n=15)$ & Bunso $(n=15)$ & Asiakwa $(n=15)$ \\
\hline Age of the decision maker (family head) $*$ & 45 & 51 & 49 \\
\hline Years spent by family head in active farming* & 23 & 19 & 15 \\
\hline Family size* & 6.4 & 5.2 & 4.5 \\
\hline Farm size* (acres) & 1.8 & 1.3 & 1.6 \\
\hline Farming system** (Dominant) & Mixed cropping & Mixed cropping & Mixed cropping \\
\hline Farm labour** (Dominant) & Family labor & Family labor & Family labor \\
\hline Land tenure** (Dominant) & Family land & Family land & Family land \\
\hline Family head & Males (five females) & Males (two females) & Males \\
\hline Migrant/native status of family head & Natives & Natives & Natives \\
\hline Level of education of family head & Elementary & Elementary & Elementary \\
\hline
\end{tabular}

Note: *mean values were calculated for respondents within each community; **Dominant farming systems, farm labor and land tenure arrangements were presented.

\subsection{Farmers' Description of Climate Change and the Associated Risks to Their Livelihoods}

Farmers were asked to share their experiences with climate change and variability with respective to their livelihoods. Their reflections could be put into six main categories (Table 2). Non consistent rainfall pattern (193), extremes in temperature (209), and reduced rainfall (188) were the main perceived changes attributed to climate change. Generally, responses 
among communities agreed except at Tafo where majority of the people noted non consistent rainfall pattern as the main attribute of climate change, whiles Bunso and Asiakwa indicated extremes in temperature.

Table 2. Perceived changes in weather in the last decade described by the farmers. The people noted more than one indications. $\sum$ percent is the sum of percentage of sample for perceived change

\begin{tabular}{|l|c|c|c|c|}
\hline \multirow{2}{*}{ Perceived change } & \multicolumn{3}{|c|}{ Communities } & \\
\cline { 2 - 5 } & Tafo (n=15) & Bunso (n=15) & Asiakwa (n=15) & E percent \\
\cline { 2 - 5 } & \multicolumn{3}{|c|}{ Percentage of sample } & \\
\hline Non consistent rainfall pattern & 63 & 59 & 71 & 193 \\
\hline Extremes in temperature & 59 & 73 & 77 & 209 \\
\hline Rainfall starts late & 23 & 39 & 15 & 77 \\
\hline Long dry seasons & 12 & 20 & 31 & 63 \\
\hline Reduced rainfall & 58 & 68 & 62 & 188 \\
\hline High intensity rainfall & 9 & 12 & 15 & 36 \\
\hline
\end{tabular}

Farmers explained their description of the changes in climate which were summarised as follows. One farmer explained that, 'in the olden days, we could tell when to start land preparation and when to plant, but now we wait for rain signs because we don't know when to start' (Bunso, $2^{\text {nd }}$ February 2015). Another farmer added that, 'do you know that late in December when the rain was supposed to cease there were still massive rains in Dunkwa- a district in the central region of Ghana' (Bunso, $4^{\text {th }}$ March 2015). Others noted the amount of rains that fall per period has reduced, 'nowadays it rains heavily but for a very short time compared to the past when it could rain for a whole month' (Tafo, $20^{\text {th }}$ February 2015). Some of the farmers held the view that the intensity of the sun is very high off late compared to years back. One cocoa farmer asserted that, 'there was planting season from March through May to July, so we usually plant from March, April and July... there was sunshine but it wasn't destroying our crops, in those days we only perform weed control on our farms but now things have changed, the weather patterns aren't like it used to be, the sun heats a lot' (Tafo, 20 ${ }^{\text {th }}$ February 2015).

When asked about the causes of climate change, the farmers gave diverse reasons to include ozone layer depletion, deforestation, and spiritual causes. Some farmers explained they have heard through the media about the depletion of the ozone layer due to anthropogenic activities. Others attributed the cause to deforestation and forest degradation. They explained that Ghana used to have mass forest cover with their surrounding houses covered with bushes, but the country has lost its intense green picture which sustained heavy rains in the past. Another common explanation was attributed to punishment from God (Spiritual being) to sinful generation. On this, one herdsman explained that, 'God is bringing judgement on people and very soon HE will come, so what we are seeing are signs of His coming' (Asiakwa, $18^{\text {th }}$ March 2015). Few others noted they were aware of changes in climate, but do not know the causes.

Farmers indicated the kinds of climate risks affecting their livelihoods which fell under eight 
main lists (Table 3). Poor crop yield (222), failure of crops to germinate (215), and high outbreaks of diseases and pest (161) were noted as the main climate induced risks across the communities. On the other hand, depressions (10), poor nutrition (38), and unclean water (48) were the least indicated among the lists. The people noted that poverty has intensified off late and attributed that to climate change, this was echoed by one local chief who reflected the views of many people, 'in this community, there are only few people who are rich, few people can send their children to better schools and this situation has been around for many years...but in recent times due to the changes in the climate, most of our people have been complaining a lot about failures in their farm works and the reduction of crop yields...this has increased poverty in this community' (Bunso, $4^{\text {th }}$ March 2015).

Table 3. Farmers indication of climate risks affecting their livelihoods. The people noted more than one indication. $\sum$ percent is the sum of percentage of sample for perceived change

\begin{tabular}{|l|c|c|c|c|}
\hline \multirow{2}{*}{ Climate risks } & \multicolumn{3}{|c|}{ Communities } & \\
\cline { 2 - 5 } & Tafo $(\mathrm{n}=15)$ & Bunso (n=15) & Asiakwa (n=15) & $\sum$ percent \\
\cline { 2 - 5 } & \multicolumn{3}{|c|}{ Percentage of sample } & \\
\hline Poor crop yield & 82 & 69 & 71 & 222 \\
\hline Failure of crops to germinate & 75 & 68 & 72 & 215 \\
\hline High outbreaks of diseases and pest & 63 & 55 & 43 & 161 \\
\hline Water shortages & 44 & 10 & 8 & 62 \\
\hline Unclean water & 38 & 7 & 3 & 48 \\
\hline Poor nutrition & 18 & 12 & 8 & 38 \\
\hline Poverty and loss of capital & 18 & 52 & 21 & 91 \\
\hline Depressions & 3 & 5 & 2 & 10 \\
\hline
\end{tabular}

\subsection{Farmers' Adaptation Responses to Climate Change}

The results show that farmers undertake various activities to cope with the changing climate and the associated risks (Table 4). The main actions noted by the farmers were the use of drought tolerant crop varieties (218), mixed species cropping (194), short rotation cropping (168), pest and disease resistant crops (164), cultivation of available crops (142), and waiting for signs of rain (110). One farmer explained that, "what we do now is to wait for the rains to start before we plant or else it will not help in the growth of our plants, but now the rains too don't come on time' (B, $12^{\text {th }}$ February 2015). Others asserted that 'we weed our farms and wait for the sun to shine on them then we burn and wait for the rains to fall' (Tafo, $11^{\text {th }}$ February 2015). Few others noted that they cultivate on floodplains and valleys (74), and put up irrigation and water harvesting systems (61). Attempt to distinct farmers' choices of climate strategies into indigenous and introduce categories failed because majority of the farmers could not make that separation, few who attempted said they were unsure.

Table 4. Farmers' responses to climate risks affecting their livelihoods. The people noted more than one indication. $\sum$ percent is the sum of percentage of sample for perceived change

\begin{tabular}{|l|l|l|l|l|}
\hline \multirow{2}{*}{ Strategies } & \multicolumn{3}{|c|}{ Communities } & \\
\cline { 2 - 5 } & Tafo $(\mathrm{n}=15)$ & Bunso $(\mathrm{n}=15)$ & Asiakwa $(\mathrm{n}=15)$ & $\sum$ percent \\
\hline
\end{tabular}




\begin{tabular}{|l|c|c|c|c|}
\hline & \multicolumn{3}{|c|}{ Percentage of sample } & \\
\hline Cultivation on floodplains and valleys & 34 & 22 & 18 & 74 \\
\hline Irrigation and water harvesting & 23 & 10 & 28 & 61 \\
\hline Short rotation cropping & 44 & 65 & 59 & 168 \\
\hline Mixed species cropping & 56 & 66 & 72 & 194 \\
\hline Pest and disease resistant crops & 38 & 59 & 67 & 164 \\
\hline Drought tolerant crop varieties & 73 & 77 & 68 & 218 \\
\hline Wait for signs of rain & 29 & 43 & 38 & 110 \\
\hline Cultivation of available crop varieties & 48 & 55 & 39 & 142 \\
\hline
\end{tabular}

When asked about the current (more recent) strategies implemented by farmers, the results revealed no clear distinction between previous and current responses (Table 5). Short rotation cropping and drought tolerant crop varieties had above 50\% indication for both previous strategies and current strategies. Other responses like cultivation on floodplains and valleys, the use of pest and disease resistant crops, and cultivation of available crop varieties did not differ much between previous and current strategies. Also, there was an indication that the people have been practicing their choices of climate strategies for quite some time. The least years was two, whiles majority of them noted they have practiced adaptation strategies above three years. One man said that 'I can't tell the number of years but I know it is many years now because I am 42 years now and I came to meet my family members planting close to rivers and using waters from the river to irrigate their crops' (Asiakwa, 12 ${ }^{\text {th }}$ March 2015).

Table 5. Farmers categorization of previous and current climate strategies $(n=45)$. The people noted more than one indication.

\begin{tabular}{|l|c|c|}
\hline \multirow{2}{*}{ Strategies } & Previous strategies & Current strategies \\
\cline { 2 - 3 } & \multicolumn{2}{|c|}{ Percentage of sample } \\
\hline Cultivation on floodplains and valleys & 55 & 49 \\
\hline Irrigation and water harvesting & 23 & 33 \\
\hline Short rotation cropping & 71 & 68 \\
\hline Mixed species cropping & 65 & 48 \\
\hline Pest and disease resistant crops & 42 & 51 \\
\hline Drought tolerant crop varieties & 63 & 59 \\
\hline Wait for signs of rain & 23 & 39 \\
\hline Cultivation of available crop varieties & 48 & 55 \\
\hline
\end{tabular}

Further analyses revealed that farmers' choices of climate strategies were largely based on personal intuition or historical experiences, status quo, knowledge of strategies, and/or availability of resources to implement a particular strategy. The views of majority of the farmers resonated in the narration of one farmer who noted that, 'I don't think we have any other choices and for me I always practice what I know, my parents were farmers and any time there are no rains, we choose to plant in the valley because over there the crops will survive' (Asiakwa, 10 ${ }^{\text {th }}$ March 2015). One old woman noted that, 'everybody does what he or she thinks will work...sometimes what you do fails but since that is what you have been doing for long, you will continue to do the same' (Asiakwa, $7^{\text {th }}$ February 2015). Another 
shared the view that 'there is a stream near our farm and usually it doesn't dry up during the dry season so we always depend on it to irrigate our vegetable crops' (Tafo, $13^{\text {th }}$ February 2015).

\subsection{Which Local Strategies Sustain Farmers' Income and Promotes Environmental Health}

Farmers were asked to reflect on how they promote sustainability in practice. Their reflections revealed three main themes associated to their understanding of sustainability. Farmers noted that sustainable practices should yield positive economic returns, but hold the view that promoting economic gains minimizes environmental health at the long term. Some share the view that sustainability could be seen as either achieving monetary profits or environmental profits, and that the farmer has a choice to make. The responses indicated that farmers largely promote real incomes by undertaking any available or known practices that could achieve that. They have limited consideration to the impact on the environment.

These assumptions were reflected in the narrations below. One woman confirmed that 'as for me, I use inorganic fertilizers on my farm, and when I plant in the valleys, I do the same. I know my actions can pollute the streams but doing that also makes my crops grow fast and healthy, nowadays the soils are not good so one must use the artificial fertilizers to supplement growth' (Asiakwa, 9th March 2015). An old farmer revealed that 'it is costly to hire labor to weed an acre of land, it is always better to spray the land with weedicides because they are less costly, no one wants to put in much cost if you don't know what you will get at the end of the growing season. I don't think this destroys the soil '(Bunso, $6^{\text {th }}$ March 2015). Another farmer indicated that 'it is not everything we do that affect the environment, planting several crops on my land does not affect the land, the only problem is that we do not get many benefits from what we plant on our farms these days. I put a lot of money into my farm works but at the end of the growing season, the returns are very few and sometimes I run at a loss' (Tafo, $3{ }^{\text {rd }}$ February. 2015). Many others shared the view that the soils within the area for some time now seems to require more external efforts to bring out the best in them. The narrative of one man was shared by many, 'the land is not good as it used to be because of the bad weather, we put a lot of pressure on the soil so they are not able to produce plenty yields as first. Also, most of the streams and lakes around our farms have been polluted by illegal miners so it is always difficult to get good water to irrigate your crops. We need the government of Ghana to do something about this (Asiakwa, $13^{\text {th }}$ February 2015). One farmer noted that, 'because the agro chemicals used sometimes pollute the air we breathe and the water bodies, everything is changing and the profits we get from our farms are reducing' (Tafo, $15^{\text {th }}$ March 2015). Others said 'the burning of weeds makes the atmosphere very hot and also the cutting down of trees during land clearing result in climate change (Bunso, $4^{\text {th }}$ March 2015).

Farmers could not give precise monetary notation for the cost of the different climate strategies they implemented on their farms. However, they provided some proxies to express the extent of the cost attached to such strategies. The notations from the farmers revealed that all the strategies have some cost element, and that farmers do not have the freedom of not incurring any cost with any of the strategies selected. These costs were measured in the cost 
of labor hired to work on their farms, the time one spends to work on a particular strategy (opportunity cost), and the cost incurred when the strategies implemented could not yield the anticipated results. On this, some responses were, 'it is costly because you have to hire labor to do the weeding for you and also you have to burn and if the rain doesn't come on time you will lose because the weeds will grow again' (Bunso, $6^{\text {th }}$ March 2015). Others noted that 'very costly because of the irrigation channels that are used in my farm, and at times I do fetch water from nearby streams' (Tafo, $8^{\text {th }}$ March 2015).

Further analyses sought to categorise adaptation practices based on the extent farmers agree the adaptation strategies sustain income and promote environmental quality. Farmers varied with the types of adaptation practices and the periods the practices have been implemented. For clarity of analyses, no specific reference time was made, farmers were rather asked to list all the practices they have used before and indicate which are profitable and those that advance environmental health. The analyses revealed that all the existing climate strategies increase farmers' income and also promote the environmental quality of their farms to some extent (Table 6). However, short rotation crops (86), mixed species cropping (77), farming at several locations (58), and drought tolerant crop varieties (72) were noted to sustain highest incomes. Similarly, the farmers identified short rotation crops (76), mixed species cropping (83), farming at several locations (63), Pest and disease resistant crops (60), and drought tolerant crop varieties (63) to be strategies with positive impact on the environment.

Table 6. Farmers categorization of sustainable climate strategies $(n=45)$. The people noted more than one indication.

\begin{tabular}{|l|c|c|}
\hline Strategies & Increase income & Promote environment health \\
\hline & \multicolumn{2}{|c|}{ Percentage of sample } \\
\hline Cultivation on floodplains and valleys & 22 & 35 \\
\hline Irrigation and water harvesting & 35 & 41 \\
\hline Short rotation cropping & 86 & 76 \\
\hline Mixed species cropping & 77 & 83 \\
\hline Pest and disease resistant crops & 56 & 60 \\
\hline Drought tolerant crop varieties & 72 & 63 \\
\hline Wait for signs of rain & 13 & 12 \\
\hline Cultivation of available crop varieties & 49 & 15 \\
\hline Farming at several locations & 58 & 63 \\
\hline
\end{tabular}

The reasons revealed three main traits for strategies that were sustainable. One, farmers noted that strategies that were of low implementation cost were mostly sustainable for them. All strategies have cost element attached, but some have minimal implementation cost compared to others. A strategy like creating water channels for irrigation was explained to be expensive depending on the nearness of water source to the farmer's farm and the number of channels to be constructed. Similarly, water harvesting requires storage containers which could pose significant cost to the farmers. Two, strategies that were flexible to precipitation and temperature were also explained to be sustainable in many counts. A typical example noted was multiple cropping, where various species of crops were planted on the same piece of land. 
It was explained that such planting technique was resilient to variations in rainfall and temperature, and that farmers would always have positive yield irrespective of the weather situation. Three, Farmers also had concerns for their environment. With the long term environmental quality in mind, farmers noted that strategies that have no negative or minimal impact on the environment had sustained benefits. Typical of such strategies were the use of disease and pest resistant crops, and the technique of having multiple farms at different locations. Farmers compared such approaches to farming in the valleys, for instance, and explained that the rivers within the valley catchment get contaminated and communities close to the farms get deprived of clean and safe drinking water.

\section{Discussions}

\subsection{Sustainability of Adaptation Strategies}

The findings from the study revealed that farmers at Eastern Ghana are confronted by climate risks, and the use of adaptation strategies to combat climate induced risks is not a new phenomenon to them (Tables 5.3, 5.4). Farmers' choices of climate strategies were influenced by factors such as historical experience, status quo, and knowledge of strategies. This is contrary to previous evidence that noted formal education, presence of a market, informal credit, and farmer-to- farmer extension (Osei-Owusu et al., 2012). The bulk of the evidence suggests that farmers' choices of climate adaptation strategies were to promote general income with minimal consideration for environmental health.

The types of adaption strategies used by the farmers were by no means unique to the study areas (Tables 4, 5), other studies have documented similar practices in the northern (CARE, 2009; Mabe et al., 2012), and other parts of Ghana (Gyampoh et al., 2009). For instance, a study conducted in the northern Ghana revealed that timing of the onset of the rainy season, soil and plant health related strategies were the most important climate related strategies to the local farmers (Osei-Owusu et al., 2012). Internal migration is common in Ghana, farmers from poor agricultural production sites mainly northern Ghana travel to the southern sector to farm or engage in other trade. It is also common for farmers from certain part of southern Ghana like Ashanti Region to relocate to Western Region to engage in cocoa farming. Through the north-south or south-south migrations, culture exchanges occur where foreign practices could be introduced to local farmers. This might explain the similarities in climate adaptation practices in the country.

The revelation that famers have few adaptation strategies at their disposal might limit their adaptive potential (Table 4). Elsewhere, climate adaptation strategies with limited direct dependence on farmers' livelihoods such as keeping personal savings or insurance to cover the expected damage have been documented (IPCC, 2001; Toman and Bierbaum, 1996). Inclusion of climate adaptation strategies which do not directly depend on the livelihood of farmers into their lists might be a necessary insurance for any unexpected shock that might occur at a large scale.

However, farmers' indication that they used inorganic fertilizers and weedicides at instances when production is low shows how the whole logic of promoting economic sustainability 
could be negatively tempered at the long run. Fertilizer usage has the risk of spreading concentrated chemicals into rivers and streams, killing soil microbes, and over concentrate certain nutrients in the soils to inhibit normal plant growth. In order to ensure holistic approach to sustain production, important environmental systems must be kept at healthy levels, and these healthy levels should be in a state of improving rather than in a declining state (Memmott et al., 2013; Jenkins, 2010). This is, however, not the case in the study areas where some of the choices of adaptation practices sustained conflicting outcomes of advancing farmer income and impacting negatively on the biophysical environment. Though the farmers were not ignorant of environmental health issues, but perceiving farming as a business with the desire to increase overall income, their choices were significantly influenced by the nature of economic returns emerging from a particular strategy. Other studies in Ghana have documented how farmers rely on adaptation strategies such as the use of compost and fertilizers as means to improve the soil nutrient to boost production (Osei-Owusu et al., 2012). The danger of this practice is the long term negative effect on the biophysical environment, and the likely reduction of future economic returns from farming on affected lands.

On the contrary, there was an indication that some climate strategies employed by the farmers like cultivation of multiple crops, and the raising of drought resistant species were both economically viable to the farmers and had no negative effect on the environment (Table 5.6). There is a strong proximity argument that the nearness of rural population to natural resources makes them the best managers of the natural resources (Cronkleton et al., 2011; Macqueen, 2011). Throughout history, local people have always had the belief to be part of natural environment, and have maintained sacred areas in the form of protected forests, nature areas, wildlife, individual plant or animal species as part of their cultures (Frumkin 2001; Burns, 2006). Their long term engagement with the natural resources have made them to gain practical knowledge on how best to protect the biophysical environment. Evidences from sub-Saharan region indicates that farmers have been conserving carbon in soils historically by using zero tillage practices in cultivation, and have used mulching techniques to moderate extreme soil temperatures, conserve moisture, suppress weed growth, and control pest and disease (Gyampoh et al., 2011; Osei-Owusu et al., 2012). Some rural communities have employed traditional conservation principles to conserve forest and wildlife (Rim-Rukeh et al., 2013; Eneji et al., 2012). Therefore, it is unsurprising for the farmers in the study area to advance climate strategies that can sustain the health of their farmlands.

\subsection{Conclusions and Implications for Policy and Practice}

The results show that climate adaptation strategies can vary with the extent they are sustainable. Farmers' choices of adaptation responses were skewed towards promoting economic sustainability with limited consideration for the health of biophysical environment. Sustainable climate strategies had low implementation cost, were flexible to precipitation and temperature, and had minimal health effect on the biophysical environment.

The discovery that climate adaptation strategies vary with the extent they advance economic and environmental sustainability has implications for environmental policies and natural 
resource management. Policy makers are institutionalising potential climate strategies across sectors such as forestry and agriculture, such measures should consider the extent the list of adaptation strategies are sustainable. Efforts should be made to document potential strategies that promote both economic and environmental sustainability. Through extension services, farmers should be informed of sustainable adaptation strategies, and farms established close to streams and rivers should be monitored periodically against the use of fertilizers and other chemicals that could infect the soil and water quality.

\section{Reference}

Action Aid. (2012). Climate resilient sustainable agriculture: a real alternative to false solution. Retrieved from http://www.actionaid.org/sites/files/actionaid/crsa _backgrounder_june_2012_design.pdf.

Ajani, E. N., Mgbenka, R. N., \& Okeke, M. N. (2013). Use of Indigenous Knowledge as a Strategy for Climate Change Adaptation among Farmers in sub-Saharan Africa: Implications for Policy. Asian Journal of Agricultural Extension, Economics \& Sociology, 2(1), 23-40. http://dx.doi.org/10.9734/ajaees/2013/1856

Antwi-Agyei, P., Andrew, J., Dougill, A. J., Evan, D. G., \& Stringer, L. C. (2012). Characterizing the nature of vulnerability to climate variability: empirical evidence from two regions of Ghana. Centre for Climate Change Economics and Policy, Working Paper No. 105, Sustainability Research Institute Paper No. 37.

Binswanger-Mkhize, H. P. (2009). Challenges and Opportunities for African Agriculture and Food Security: High Food Prices, Climate Change, Population Growth, and HIV and AIDS. Expert Meeting on How to Feed the World in 2050, Food and Agriculture Organization of the United Nations, Rome.

Black, A. (2004). The quest for sustainable, healthy communities, presented to Effective Sustainability Education Conference. NSW Council on Environmental Education. UNSW, Sydney, 18-20 February, 2004.

Burns, G. (2006). Naturally happy, naturally healthy: the role of the natural environment in wellbeing, the science of wellbeing, Oxford University Press: Oxford, 405-431.

CARE (2009). Ghana Case Study - CARE Climate Change, Participatory and inclusive planning for adaptation to climate change in Northern Ghana. Retrieved from http://www.careclimatechange.org/files/adaptation/Ghana_09.pdf

Cayan, D. R., Das, T., Pierce, D. W., Barnett, T. P., Tyree, M., \& Gershunov, A. (2010). Future dryness in the southwest US and the hydrology of the early 21 st century drought. Proc. Natl. Acad. Sci. USA, 107, 21, 271-21 276. http://dx.doi.org/10.1073/pnas.0912391107

Cayan, D., Tyree, M., Kunkel, K. E., Castro. C., Gershunov, A., Barsugli, J., Ray, A. J., Overpeck, J., Anderson, M., Russell, B., Rajogopalan, B., Rangwala, I., Duffy, P. (2013). Future climate: projected average. In Assessment of Climate Change in the Southwest United States: a Report Prepared for the National Climate Assessment. (Eds G Garfin, A Jardine, R 
Merideth, M Black, S LeRoy), 101-125. http://dx.doi.org/10.5822/978-1-61091-484-0_6

Climate and Development Knowledge Network, CDKN. (2013). Ghana: Climate Change Risk Communications Framework for Coastal Urban Development Policy. Retrieved from http://cdkn.org/wp-content/uploads/2012/03/Ghana-Coastal-Resilience_-Project-brief_May-2 013final.pdf.

Costello, A., Abbas, M., et al. (2009). Managing the health effects of climate change. UCL Institute for Global Health and Lancet Commission. Lancet, 373, 1693-1733. http://dx.doi.org/10.1016/S0140-6736(09)60935-1

Cronkleton, P., Bray, D. B., \& Medina, G. (2011). Community Forest Management and the Emergence of Multi-Scale Governance Institutions: Lessons for REDD+ Development from Mexico, Brazil and Bolivia, Forests, 2(2), 451-473. http://dx.doi.org/10.3390/f2020451

Doss, C., Morris, M. (2001). How does gender affect the adoption of agricultural innovations? The case of improved maize technology in Ghana. Agric. Econ. 25, 27-39. http://dx.doi.org/10.1016/S0169-5150(00)00096-7

Eneji, C. V. O., Ntamu, G. U., Unwanade, C. C., Godwin, A. B., Bassey, J. E., Willaims, J. J \& Ignatius, J. (2012). Traditional African Religion in Natural Resources Conservation and Management in Cross River State, Nigeria, Environment and Natural Resources Research 2(4), 45-53.

Food \& Agriculture Organization, FAO. (2005). The State of Food Insecurity in the World, Eradicating world hunger -key to achieving the Millennium Development Goals. Retrieved from ftp://ftp.fao.org/docrep/fao/008/a0200e/a0200e.pdf.

Frumkin, H. (2001). Beyond Toxicity: The greening of environmental Health, American Journal of Preventative Medicine, 234-240. http://dx.doi.org/10.1016/S0749-3797(00)00317-2

Gilbert, R., Stevenson, D., Girardet, H., \& Stern, R. (Eds.), (1996). Making Cities Work: The Role of Local Authorities in the Urban Environment. Earthscan Publications.

Goodland, R. (1995). The concept of environmental sustainability, Annual Review of Ecology and Systematics, 26, 1-24. http://dx.doi.org/10.1146/annurev.es.26.110195.000245

Government of Ghana. (2015). Eastern. Retrieved from http://www.ghana.gov.gh/index.php/ about-ghana/regions/eastern-region.

Gyampoh, B. A., Amisah, S., Idinoba, M., \& Nkem, J. (2009). Using traditional knowledge to cope with climate change in rural Ghana, Unasylva 231/232, Vol. 60, 2009.

Gyampoh, B. A., Winston, A. A, La Rose, D. J., Adu-Acheampong. G., Assimeng, T., Gyamfi, A. O. (2011). Mapping and Documenting Indigenous Knowledge in Climate Change Adaptation in Ghana. Retrieved from https://www.undp-aap.org/sites/undp-aap.org/files/Ghana_Mapping\%20and\%20Documenting \%20Indegenous\%20Knowledge\%20in\%20CCA\%20in\%20Ghana_2011.pdf. 
Hamrin, R. D. (1983). A Renewable Resource Economy. Praeger, New York.

Huber, D., \& Jay, G. (2011). Extreme Weather and Climate Change: Understanding the Link and Managing the Risk. Science and Impacts Program. Center for Climate and Energy Solutions: Arlington, VA. Retrieved http://www.c2es.org/publications/extreme-weather-and-climate-change.

International Finance Corporation, IFC. (2011). Climate Risk and Business Agribusiness. Ghana Oil Palm Development Company. Retrieved from http://www.ifc.org/wps/wcm/connect/bd7ec00048855444b214f26a6515bb18/IFC\%2BClimat e\%2BRisk-\%2BGOPDC\%2B-\%2Bexec\%2Bsummary.pdf?MOD=AJPERES.

Intergovernmental Panel on Climate Change, IPCC. (2001). Climate Change 2001: The Scientific Basis. Contribution of Working Group I to the Third Assessment Report of the Intergovernmental Panel on Climate Change.

In Houghton, J. T., Y. Ding, D. J. Griggs, M. Noguer, P. J. van der Linden, X. Dai, K. Maskell, \& C. A. Johnson (eds.)]. Cambridge University Press, Cambridge, United Kingdom and New York, NY, USA.

Intergovernmental Panel on Climate Change, IPCC. (2007). Climate Change 2007-Mitigation of Climate Change. Contribution of Working Group III to the Fourth Assessment Report of the IPCC, annual report.

Jenkins, W. (2010). Sustainability Theory. In Berkshire Encyclopedia of Sustainability: The Spirit of Sustainability, 380-384.

Kumasi Institute of Tropical Agriculture, KITA. (2015). Market for Pepper, Pineapple, Woodlot Intercrop and Energy Efficient Cook Stoves Technology in the Mfantseman Municipality of the Central Region. A Christian Aid Market Research Report February 2015.

Kreft, S., Eckstein, D., Junghans, L., Kerestan, C., \& Hagen, U. (2015). Who suffers most from extreme weather events? Weather-related loss events in 2013 and 1994 to 2013, Global Climate Risk Index 2015, briefing paper.

Kuhlman, T., Farrington, J. (2010). What is sustainability? Sustainability, 2, 3436-3448. http://dx.doi.org/10.3390/su2113436

Livingston, G., Schonberger, S., \& Delaney, S. (2011). Sub-Saharan Africa: The state of smallholders in agriculture. Paper presented at the IFAD Conference on New Directions for Smallholder Agriculture. 24-25 January 2011. Session 3. Rome: International Fund for Agricultural Development.

Mabe, F. N., Sarpong, D. B., Osei-Asare, Y. (2012). Adaptive Capacities of Farmers to Climate Change Adaptation Strategies and Their Effects on Rice Production in the Northern Region of Ghana. Russian Journal of Agricultural and Socio-Economic Sciences, No. 11 (11) / 2012.

Macqueen, D. (2011). Investing in locally controlled forestry. briefing. 
Markandya, A., \& Pearce, D. W. (1988). Natural environments and the social rate of Discount, Project Appraisal, 3(1), 2-12. http://dx.doi.org/10.1080/02688867.1988.9726647

Martin, J. P. (2001). The Social Dimensions of Sustainable Development, Speech delivered to the Conference on the European Social Agenda and EU is International Partners. Brussels, 20-21 November 2001.

Meehl, G. A., Stocker, T. F., Collins, W. D., Friedlingstein, P., Gaye, A. T., Gregory, J. M., Kitoh, A., Knutti, R., Murphy, J. M, Noda, A., Raper, S. C. B., Watterson, I. G., Weaver, A. J., \& Zhao, Z. C. (2007). Global Climate Projections. In: Climate Change 2007: The Physical Science Basis. Contribution of Working Group I to the Fourth Assessment Report of the Intergovernmental Panel on Climate Change [Solomon, S., D. Qin, M. Manning, Z. Chen, M. Marquis, K.B. Averyt, M. Tignor and H.L. Miller (eds.)]. Cambridge University Press, Cambridge, United Kingdom and New York, NY, USA.

Memmott, P., Reser, J., Head, B., Davidson, J., Nash, D., O'Rourke, T., Gamage, H., Suliman, S., Lowry, A. \& Marshall, K. (2013). Aboriginal Responses to Climate Change in Arid Zone Australia: Regional Understandings and Capacity Building for Adaptation. National Climate Change Adaptation Research Facility. Southport, QLD, Australia.

Murdiyarso, D., \& Kauffman, J. B. (2011). Addressing climate change adaptation and mitigation in tropical wetland ecosystems of Indonesia. CIFOR Infobrief.

Murdiyarso, D., Kauffman, J. B., Warren, M., Pramova, E., \& Hergoualch, K. (2012). Tropical wetlands for climate change adaptation and mitigation science and policy imperatives with special reference to Indonesia. CIFOR Working Paper.

Organisation for Economic Co-operation \& Development, OECD. (2008). Annual Report 2008. Retrieved from http://www.oecd.org/newsroom/40556222.pdf.

Osei-Owusu, Y., Al-Hassan, R. M., Doku-Marfo, E. (2012). Assessing the adaptation mechanisms of smallholder farmers to climate change and agrobiodiversity losses in northern Ghana. Retrieved from http://start.org/download/gec11/osei-final-report.pdf.

Rim-Rukeh, A., Irerhievwie, G., Agbozu I. E. (2013). Traditional beliefs and Conservation of Natural Resources: Evidences from Selected Communities in Delta State, Nigeria. Intl. J Biodiver. Conserv, 5(7), 426-432.

Rolston, H. III. (1994). Conserving natural value. New York: Columbia University Press.

Salami, A., Kamara, A. B., \& Brixiova, Z. (2010). Smallholder agriculture in East Africa: trends, constraints and opportunities, Working Paper 105, African Development Bank, Tunis, Tunisia.

Scheffran, J., \& Battaglini, A. (2011). Climate and conflicts: the security risks of global warming. Rsegional Environmental Change, 11, S27-S39. http://dx.doi.org/10.1007/s10113-010-0175-8

Scheffran, J., Brzoska, M., Kominek, J., Link, M., \& Schilling, J. (2012). Climate Change and 
Violent Conflict, Science, 336, 869-871. http://dx.doi.org/10.1126/science.1221339

Serageldin, I., \& Streeter, A. (eds.), (1993). Valuing the environment: proceedings of the

First Annual Conference on Environmentally Sustainable Development. Environmentally Sustainable Development Proceedings Series No. 2, The World Bank, Washington, D.C.

Sivakumar, M. V. K. \& Stefanski, R. (2008). Climate change mitigation, adaptation and sustainability in agriculture. In: Symposium on Climate Change and Variability, 1. 2008, Oscarsborg. Abstracts Oscarsborg: WMO, 2008.

Stanturf, J.A, Melvin, L. W., Charnley, S., Polasky, S. C., Goodrick, S. L., Armah, F., \& Nyako, Y. A. (2011). Ghana Climate Change Vulnerability and Adaptation Assessment. Retrieved from

http://www.encapafrica.org/documents/biofor/Climate\%20Change\%20Assessment_Ghana_\% 20FINAL.pdf.

Sutton, P. (2004). A Perspective on environmental sustainability? A paper for the Victorian Commissioner for Environmental Sustainability. Version 2b, 12 April 2004. Retrieved from http://www.green-innovations.asn.au/A-Perspective-on-Environmental-Sustainability.pdf.

Teodorescu, A. M. (2012). Links Between the Pillars of Sustainable Development. Retrieved from http://feaa.ucv.ro/annals/v1_2012/EIB-12.pdf.

Toman, M. A., \& Bierbaum. R. (1996). An Overview of Adaptation to Climate Change. In J. B. Smith et al. (eds.) Adapting to Climate Change: An International Perspective (New York: Springer-Verlag). http://dx.doi.org/10.1007/978-1-4613-8471-7_2

United Nations Department of Economic and Social Affairs, UNDESA. (2008). Addressing climate change in national sustainable development strategies common practices. Background Paper NO. 12.

United Nations Development Programme, UNDP. (2012). National Climate Change Adaptation Strategy. Retrieved from http://www.google.co.uk/url?sa=t\&rct=j\&q=\&esrc=s\&source=web\&cd=1\&ved=0CC

EQFjAA\&url=http $\% 3 \mathrm{~A} \% 2 \mathrm{~F} \% 2 \mathrm{Fwww}$.undp-alm.org\%2Fsites $\% 2 \mathrm{Fdefault} \% 2 \mathrm{Ffiles} \% 2 \mathrm{Fdownl}$ oads\%2Fghana_national_climate_cha

nge_adaptation_strategy_nccas.pdf\&ei=EsyEVYbsOpW0yASQroLwDw\&usg=AFQj

CNEthrsS1veGvgRZnhJvjq8v9NCXSw\&sig2=A3n0KTTitBoxjwYx6qQYiA.

United Nations Development Programme, UNDP. (2010). Climate Change Adaptation Strategy and Programme of Action for the Palestinian Authority. Retrieved from http://www.arabstates.undp.org/content/dam/papp/docs/Publications/UNDP-papp-research-cli matechange.pdf.

United Nations Framework Convention on Climate Change. (2008). Climate Change: Impacts, Vulnerabilities and Adaptation in Developing Countries. UNFCCC Secretariat, Bonn. Retrieved from http://unfccc.int/files/essential background/background_publications_htmlpdf/applica tion/txt/pub_07_impacts.pdf 


\section{Macrothink}

Environmental Management and Sustainable Development

ISSN 2164-7682 2016, Vol. 5, No. 2

United States Agency for International Development, USAID. (2012), USAID Climate Change Adaptation Plan. Retrieved from https://www.usaid.gov/sites/default/files/documents/1865/Agency\%20Climate\%20Change\%2 0Adaptation\%20Plan\%202012.pdf.

Wheeler, D. (2011). Quantifying Vulnerability to Climate change: Implications for Adaptation Assistance, Center for Global Development. Working Paper 240.

Wilkins, H. (2009). The integration of the pillars of sustainable development: a work in progress. JSDLP RDPP, Volume 2, pp.163 -188.

World Bank. (2006). Where is the Wealth of Nations? Measuring Capital for the $21^{\text {st }}$ Century. WB, Washington, D.C.

\section{Copyright Disclaimer}

Copyright for this article is retained by the author(s), with first publication rights granted to the journal.

This is an open-access article distributed under the terms and conditions of the Creative Commons Attribution license (http://creativecommons.org/licenses/by/3.0/). 